\title{
ANALISIS TEMATIK SEBAGAI METODE ANALISA JOB INSECURITY PADA KARYAWAN MASKAPAI PENERBANGAN DI MASA COVID-19
}

\author{
Olivia Margareth Simamora, Anissa Lestari Kadiyono \\ Email: olivia19003@mail.unpad.ac.id
}

\section{Fakultas Psikologi, Universitas Padjadjaran}

\begin{abstract}
The Covid-19 pandemic has weakened several industrial sectors, including the aviation industry. This uncertain situation, pressing conditions and changing work environment puts pressure on the existence of airlines and anxiety for its human resources. This research wants to describe how the job insecurity phenomenon is among airline employees. The study was conducted using a qualitative research approach using thematic analysis techniques and interviews as an assessment medium and using a purposive sampling technique. Thematic analysis is a data analysis technique used in qualitative research where the researcher collects descriptive data to answer research problems. Once the data is collected, the researcher continues to read the data with the intention of finding patterns, themes, sub-themes, and so on. The results of the research found that the Covid-19 pandemic directly contributed to changes in the organizational system which then made airlines implement rules such as changing work schedules, cutting wages, making adjustment to employee duties and functions, and laying off employees. Furthermore, this change in the organizational system has several impacts, such as a decrease in work productivity, employees doing things outside their main task, dissatisfaction at work, financial problems, and a tendency to turnover. The results of this study describe the dimensions of job insecurity, antecedent factors, and consequent factors.
\end{abstract}

Keyword: Airlines, Covid-19, Job Insecurity, Thematic Analysis

\begin{abstract}
Abstrak. Pandemi Covid-19 telah melemahkan beberapa sektor industri, termasuk dalam industri penerbangan. Situasi yang tidak pasti, kondisi yang menekan dan lingkungan kerja yang berubah ini memberikan tekanan terhadap eksistensi maskapai penerbangan dan kecemasan pada para SDM-nya. Penelitian ini ingin menggambarkan bagaimana fenomena job insecurity pada karyawan maskapai penerbangan. Penelitian dilakukan menggunakan pendekatan penelitian kualitatif dengan menggunakan teknik analisis tematik dan wawancara sebagai media assesment serta menggunakan teknik purposive sampling. Analisis tematik adalah teknik analisis data yang digunakan dalam penelitian kualitatif dimana peneliti mengumpulkan data deskriptif untuk menjawab permasalahan penelitiannya. Begitu data dikumpulkan, peneliti akan terus-menerus membaca data dengan maksud menemukan pola, tema, sub tema, dan sebagainya. Hasil penelitian yang ditemukan adalah pandemi Covid-19 secara langsung menjadi faktor penyebab terjadinya perubahan sistem organisasi yang kemudian membuat maskapai penerbangan menerapkan aturan seperti perubahan jadwal kerja, pemotongan gaji, melakukan penyesuaian terhadap tugas dan fungsi karyawan, hingga melakukan PHK. Selanjutnya perubahan sistem organisasi ini menimbulkan beberapa dampak seperti penurunan produktivitas kerja, karyawan mengerjakan hal di luar tugas utama, ketidakpuasan dalam bekerja, masalah finansial, dan kecenderungan untuk turnover. Hasil penelitian ini menggambarkan dimensi job insecurity, faktor anteseden dan faktor konsekuen.
\end{abstract}

Kata Kunci: Analisis Tematik, Covid-19, Job Insecurity, Maskapai Penerbangan

29 | Psychophedia Jurnal Psikologi Universitas Buana Perjuangan Karawang 


\section{Pengantar}

Covid-19 merupakan fenomena pandemi yang setahun ke belakang menjadi perhatian seluruh dunia. Di Indonesia sendiri Covid-19 mulai menyebar pada bulan Maret 2020. Sejak saat itu tercatat sebanyak 1,22 juta orang pernah terpapar virus Covid-19, diantaranya 1,03 juta orang sembuh dan 33.367 orang lainnya meninggal dunia. Setelah Covid-19 mewabah di Indonesia, telah banyak kebijakan yang diterapkan oleh pemerintah pusat maupun pemerintah daerah. Tercatat sepanjang semester I-2020, pemerintah menitikberatkan pada kampanye penerapan protokol kesehatan, penetapan PSBB, dan wajib tes Covid-19 apabila hendak berpergian. Kebijakan pemerintah yang membatasi aktivitas masyarakat berpengaruh pada aktivitas bisnis yang kemudian berimbas pada perekonomian negara. Kegiatan bisnis pada masa pandemi belum sepenuhnya berjalan dengan normal, karena masih dibatasi oleh kebijakan pemerintah untuk menekan penyebaran virus Covid-19 (Gitiyarko, 2020). Laporan Badan Pusat Statistik (BPS) menyebut bahwa pertumbuhan ekonomi Indonesia pada kuartal II 2020 minus 5,32 persen (Sayekti, 2020).

Salah satu industri yang mengalami dampak paling dalam adalah sektor transportasi, khususnya dalam industri penerbangan (Artanti, 2020). Pelaku industri penerbangan, merasakan adanya penurunan jumlah penumpang, sehingga menyebabkan industri ini mengalami kerugian yang sangat besar. Sejak Covid-19 mewabah di Indonesia, terlihat ada penurunan jumlah penerbangan pesawat untuk rute dalam negeri maupun rute internasional. Berdasarkan data yang dihimpun dari Badan Pusat Statistik, tercatat bahwa sepanjang tahun 2020 jumlah penumpang yang melakukan perjalanan domestik sebesar 32,39 juta orang. Jumlah ini menurun $57,76 \%$ dari tahun 2019 yang sebesar 76,69 juta orang. Angka penurunan yang lebih drastis terekam untuk penerbangan rute internasional.
Sepanjang 2020 tercatat ada sebanyak 3,5 juta penumpang internasional atau turun sebesar $74,54 \%$ dibandingkan jumlah penumpang pada tahun sebelumnya (Hadiwinata, 2020).

Penurunan penggunaan transportasi penerbangan dipengaruhi oleh beberapa hal salah satunya pada sektor pariwisata, dimana sebagian masyarakat memilih untuk tidak melakukan perjalanan liburan karena ada beberapa objek wisata yang dikurangi jam operasionalnya atau bahkan ditutup sementara oleh pelaku bisnis untuk menghindari kerugian yang lebih besar. Selain itu, masyarakat juga masih dihantui oleh perasaan khawatir tertular virus Covid-19 apabila mereka melakukan perjalanan liburan. Kemudian selama pandemi, proses penyelenggaraan suatu kegiatan banyak mengalami perubahan cara, dimana jika sebelumnya kegiatan dilakukan secara tatap muka, saat ini sebagian besar kegiatan dialihkan ke metode daring. Misalnya saja kegiatan perjalanan dinas yang saat ini intensitasnya mengalami penurunan, sehingga ikut berdampak pada jumlah penggunaan transportasi umum khususnya pesawat.

Maskapai penerbangan " $\mathrm{X}$ " yang menjadi responden dalam penelitian ini, turut terkena dampak Covid-19. Sampai saat ini jumlah penumpang yang melakukan penerbangan bersama maskapai penerbangan " $X$ ", masih belum mencapai titik normal seperti sebelum terjadinya pandemi. Pada April 2020 sebagai respon terhadap kebijakan pemerintah, maskapai penerbangan " $X$ " sempat menutup hampir seluruh penerbangan khusus penumpang. Perusahaan hanya membuka penerbangan khusus darurat seperti pengiriman logistik maupun untuk keperluan pemerintah. Saat itu perusahaan mengalami kerugian sangat besar hingga menyentuh angka triliunan rupiah.

Pandemi yang masih berlangsung sampai saat ini, memaksa perusahaan untuk melakukan perubahan organisasi seperti perubahan jadwal kerja, pemotongan gaji, 
melakukan penyesuaian terhadap tugas dan fungsi karyawan, hingga melakukan PHK. Perusahaan menetapkan kebijakan pemotongan gaji sebesar $50 \%$ bagi seluruh karyawan, pilot, dan pramugari. Kebijakan tersebut mulai diberlakukan pada bulan Mei 2020 hingga saat ini dan tidak dapat dipastikan akan sampai kapan kebijakan tersebut diberlakukan. Selain berkurangnya jumlah pemasukan perusahaan, alasan lain kebijakan pemotongan gaji dikarenakan selama pandemi jumlah jam dan hari kerja karyawan berkurang drastis.

Karyawan merasa khawatir akibat kebijakan pemotongan gaji yang cukup besar. Ditambah lagi, kebijakan tersebut akan berlangsung sampai waktu yang tidak dapat ditentukan. Dengan nominal gaji saat ini, karyawan merasakan beban finansial dan harus lebih berhati-hati dalam mengatur keuangan. Selain itu mereka merasa khawatir dengan perjalanan karir mereka, karena sebelumnya ada sebagian besar karyawan yang diberhentikan oleh perusahaan. Mereka khawatir apabila di kemudian hari akan mengalami hal yang serupa. Tetapi meskipun kebijakan tersebut dinilai merugikan, karyawan memilih untuk tetap bertahan di perusahaan karena tidak memiliki alternatif pekerjaan lain apabila ingin mengundurkan diri. Apalagi di masa pandemi, dimana mayoritas perusahaan membatasi kegiatan rekrutmen SDM baru. Karyawan menganggap kebijakan pemotongan gaji masih lebih baik daripada mereka harus di PHK dan tidak memiliki pekerjaan.

Situasi yang dialami karyawan mengindikasikan adanya job insecurity pada karyawan. Job insecurity adalah kondisi mental seorang karyawan dimana karyawan merasa pekerjaannya terancam dan karyawan tidak berdaya untuk melakukan sesuatu untuk mengatasi masalah tersebut (Ashford, 1989). Lebih lanjut Greenhalgh \& Rosenblatt (1984) menjelaskan job insecurity adalah persepsi terhadap ancaman terhadap masa depan pekerjaan seperti kesempatan untuk promosi atau kebebasan untuk mengatur waktu kerjanya sendiri, semakin besar seorang mempersepsikan ancaman terhadap pekerjaannya di masa depan maka semakin besar pula job insecurity.

Perusahaan " $X$ " bergerak di bidang pelayanan jasa penerbangan, dimana sumber utama keuangan berasal dari permintaan konsumen. Sampai saat ini belum dapat dipastikan akan sampai kapan pandemi berlangsung. Selama masih ada pandemi dan kebijakan pemerintah yang membatasi mobilitas masyarakat, maka proses bisnis perusahaan " $X$ " belum dapat pulih seutuhnya. Situasi ini akan terus menjadi sebuah ancaman pada aspek pekerjaan karyawan yang dapat berimbas pada kondisi mental mereka. Job insecurity dapat mengakibatkan stres, kecenderungan untuk turnover, penurunan komitmen organisasi, dan ketidakpuasan kerja. Maka dari itu, peneliti tertarik melakukan penelitian untuk mengenai gambaran job insecurity pada karyawan perusahaan maskapai penerbangan " $\mathrm{X}$ " selama masa pandemi.

\section{Landasan Teori}

Ashford (1989) mengatakan bahwa job insecurity adalah kondisi mental seorang karyawan dimana karyawan merasa pekerjaannya terancam dan karyawan tidak berdaya untuk melakukan sesuatu untuk mengatasi masalah tersebut. Lebih lanjut Greenhalgh \& Rosenblatt (1984) menjelaskan job insecurity adalah persepsi terhadap ancaman terhadap masa depan pekerjaan seperti kesempatan untuk promosi atau kebebasan untuk mengatur waktu kerjanya sendiri, semakin besar seorang mempersepsikan ancaman terhadap pekerjaannya di masa depan maka semakin besar pula job insecurity.

Greenhalgh \& Rosenblatt (1984) menyatakan terdapat dua dimensi dari job insecurity, yaitu:

1. Severity of threat: tingkat job insecurity karyawan dipengaruhi oleh seberapa 
banyak atau seberapa besar ancaman yang muncul dari aspek-aspek pekerjaan yang berpotensi menimbulkan kerugian. Tingkat ancaman yang dipersepsikan tidak lepas dari pengaruh karakteristik individual. Greenhalg \& Rosenblatt (1984) menyatakan ada beberapa sumber ancaman yang dapat dipersepsikan secara negatif oleh karyawan seperti ancaman kehilangan pekerjaan, perkembangan karir yang tidak sesuai harapan, aliran pemasukan, kehilangan status, berkurangnya otonomi dan sumber daya, kehilangan komunitas kerja, perubahan organisasi seperti kemunduran organisasi, reorganisasi, dan perubahan teknologi.

2. Powerlessness to counteract the threat: yaitu ketidakmampuan karyawan untuk menghadapi situasi penuh ancaman akan berakibat pada semakin tinggi atau rendahnya job insecurity. Greenhalg dan Rosenblatt (1984) menyatakan ada empat bentuk powerlessness yaitu lack of protection, unclear expectancies, authoritarian environment, dan dismissal SOP.

Selain itu Ashford et al., (1989) menyatakan terdapat tiga anteseden dari job insecurity, yaitu:

1. Perubahan organisasi: situasi pekerjaan yang tidak dapat dikendalikan atau diprediksi oleh karyawan dapat menimbulkan perasaan tidak aman. Salah satu ancaman yang sering muncul adalah perubahan organisasi dalam skala besar, seperti downsizing, restrukturisasi, merger, teknologi baru, dan PHK.

2. Ambiguitas peran: ambiguitas peran mengancam rasa kendali karyawan sehingga menciptakan persepsi job insecurity, karena terkait kurangnya informasi tentang persyaratan dan prosedur pekerjaan. Dengan kelangkaan informasi konkret tentang peran, karyawan mungkin berspekulasi tentang berbagai peristiwa yang dapat berdampak negatif terhadap pekerjaan.

3. Locus of control: dibandingkan dengan karyawan dengan lokus kontrol eksternal, karyawan yang memiliki lokus kontrol internal umumnya melihat peristiwa lingkungan memiliki dampak yang lebih kecil dan percaya bahwa mereka memiliki kekuatan untuk melawan ancaman yang ditimbulkan oleh lingkungan mereka (Mitchell \& Moudgill, 1976; Rotter, 1966)

Ashford et al., (1989)juga menyatakan bahwa terdapat empat konsekuen dari job insecurity, yaitu:

1. Stres: job insecurity dapat menimbulkan rasa takut, kehilangan kemampuan, dan kecemasan. Pada akhirnya, jika hal ini dibiarkan berlangsung lama karyawan dapat menjadi stres akibat adanya rasa tidak aman dan ketidakpastian akan kelangsungan pekerjaan.

2. Keinginan untuk turnover: job insecurity dapat berhubungan dengan respon penarikan diri sebagai usaha untuk menghindari stres. Semakin besar job insecurity dapat meningkatkan perilaku mencari peluang kerja yang lebih aman (Greenhaigh \& Rosenblatt, 1984). Karyawan yang menganggap dirinya akan mudah mendapatkan pekerjaan baru, akan semakin meningkatkan intensi untuk keluar dari pekerjaannya.

3. Komitmen organisasi dan kepercayaan terhadap organisasi menurun: tingkat $j o b$ insecurity dapat mempengaruhi persepsi terhadap organisasi dan keterikatan afektif yang telah terjalin. Karyawan mengharapkan organisasi dapat berperan mengurangi ancaman yang muncul pada aspek-aspek pekerjaan. Apabila menurut karyawan organisasi tidak dapat diandalkan untuk mengurangi atau menghilangkan ancaman yang ada, dapat menurunkan komitmen dan kepercayaan karyawan terhadap organisasi. 
Kesejahteraan yang ditawarkan oleh organisasi dapat mempengaruhi pilihan pegawai untuk tetap bertahan atau sebaliknya.

4. Kepuasan kerja yang rendah: karyawan dengan job insecurity tinggi akan kurang puas dengan pekerjaan mereka. Kepuasan kerja adalah kondisi dimana karyawan merespon positif dan menerima secara efektif pekerjaan mereka. Apabila karyawan mempersepsikan pekerjaan secara negatif, maka dapat menurunkan tingkat kepuasan kerja.

\section{Metode Penelitian}

Penelitian dilakukan menggunakan pendekatan penelitian kualitatif dengan wawancara sebagai media asesmen serta menggunakan teknik purposive sampling yang merupakan teknik non random sampling (Sugiyono, 2012), sehingga peneliti memilih sampel yang sesuai dengan kriteria sehingga diharapkan dapat menjawab permasalahan penelitian. Responden berjumlah dua orang yang berasal dari dua divisi yaitu divisi Legal (responden A) dan divisi Pengadaan Barang (responden B). Wawancara dilakukan pada dua hari berbeda dengan menggunakan aplikasi Whatsapp. Wawancara dilakukan secara online dikarenakan responden berdomisili di luar kota- Penyusunan pertanyaan wawancara menggunakan teori job insecurity. Hasil wawancara kemudian dianalisis menggunakan teknik analisis tematik (Braun \& Clarke, 2006). Peneliti akan membaca transkrip wawancara dan kemudian melihat tema mana yang paling sering muncul dalam transkrip.

Menurut Braun dan Clarke (2006), analisis tematik dapat dipecah menjadi enam tahap berurutan, dimana dalam proses analisisnya akan terjadi proses tumpang tindih karena Hasil Dan Pembahasan

Tingkat job insecurity karyawan dipengaruhi oleh seberapa banyak atau seberapa besar ancaman yang muncul dari aspek-aspek pekerjaan yang berpotensi seperti pada umumnya analisis kualitatif membutuhkan proses maju - mundur untuk meningkatkan kualitas analisis.

1. Pengenalan data: sebagai tahapan paling awal, dimana peneliti melakukan pengenalan terhadap transkrip data melalui proses membaca.

2. Pembuatan initial coding: merupakan proses awal sebelum menentukan tema besar, dengan mencari tahu esensi dari setiap satu atau dua baris kalimat.

3. Mencari Tema Berdasarkan Initial Coding: initial coding menghasilkan kode-kode dari sekumpulan data. Langkah selanjutnya adalah menentukan tema besar berdasarkan keterkaitan antara kode. Tema yang berkualitas adalah tema yang memiliki tingkat abstraksi tinggi dan mampu menggambarkan kode-kode di dalamnya.

4. Ulasan Tema: peneliti melakukan pemeriksaan ulang terhadap tema untuk memastikan apakah tema yang telah ditentukan sudah sesuai dengan data aslinya. Pada tahap ini mungkin terjadi modifikasi tema, misalnya apabila ditemukan bahwa kode-kode di dalam suatu tema sebenarnya tidak memiliki keterkaitan, sehingga perlu dikonstruk dua tema atau sub tema yang berbeda.

5. Definisi dan Pelabelan Tema: melakukan pemeriksaan ulang terhadap sekumpulan tema dan memastikan bahwa antar tema dapat dibedakan secara konseptual.

6. Penulisan Laporan: penulisan kualitatif cenderung mencakup lebih banyak deskripsi tentang masalah analisis daripada bentuk lain dari laporan penelitian. Dalam laporan perlu memasukkan banyak detail tentang proses analitik.

menimbulkan kerugian atau yang disebut dengan tingkat keparahan ancaman/severity of threat (Greenhalgh \& Rosenblatt, 1984). Ancaman yang timbul dari aspek pekerjaan 
seperti ancaman kehilangan pekerjaan, perkembangan karir yang tidak sesuai harapan, aliran pemasukan, kehilangan status, berkurangnya otonomi dan sumber daya, kehilangan komunitas kerja, perubahan organisasi seperti kemunduran organisasi, reorganisasi, dan perubahan teknologi. Sampai saat ini perusahaan masih menetapkan kebijakan pemotongan gaji kebutuhan sehari-hari, responden melakukan strategi pengelolaan keuangan seperti memenuhi kebutuhan prioritas terlebih dahulu dan menunda kebutuhan yang bukan prioritas, mengurangi penggunaan listrik, serta mengatur penggunaan barangbarang lainnya.

Menurut Greenhalgh \& Rosenblatt (1984), jika individu menerima ancaman pada aspek kerja atau kejadian kerja maka mereka akan menghadapinya sesuai kemampuan yang dimiliki. Semakin tinggi atau rendahnya powerlessness to counteract the threat akan berakibat semakin tinggi atau rendahnya job insecurity yang dirasakan individu. Kedua responden menunjukkan reaksi yang hampir serupa, mereka merasa pasrah terhadap kebijakan yang telah di tetapkan. Mereka tidak dapat melakukan hal lain, selain bekerja seperti biasa dan menerima kebijakan tersebut. Di sisi lain mereka merasa bersyukur karena sampai saat ini perusahaan tidak melakukan PHK terhadap mereka. Menurut responden, kebijakan ini merupakan langkah terbaik bagi karyawan maupun perusahaan. Menurut responden A, gaji yang diterima saat ini sudah seimbang seiring dengan menurunnya tingkat produktivitas kerja. Responden A menyadari bahwa tidak mungkin ia memaksa perusahaan membayar nominal gaji sama seperti sebelum terjadi pandemi, karena pemasukan perusahaan saat ini mengalami penurunan sangat drastis.

Situasi pekerjaan yang tidak dapat dikendalikan atau diprediksi oleh karyawan dapat menimbulkan perasaan tidak aman. Salah satu ancaman yang sering muncul sebesar 50\% bagi seluruh karyawan, pilot, dan pramugari. Responden menilai gaji merupakan aspek penting karena bermanfaat untuk memenuhi kebutuhan sehari-hari. Kebijakan perusahaan dengan melakukan pemotongan gaji sebesar $50 \%$ sangat mempengaruhi kondisi finansial responden. Menurut mereka jumlah pemotongan tersebut tidaklah kecil. Supaya tetap dapat memenuhi adalah perubahan organisasi dalam skala besar, seperti downsizing, restrukturisasi, merger, teknologi baru, dan PHK (Ashford et al.,1989). Pandemi yang masih berlangsung sampai saat ini, memaksa perusahaan untuk melakukan perubahan organisasi seperti perubahan jadwal kerja, pemotongan gaji, melakukan penyesuaiaan terhadap tugas dan fungsi karyawan, hingga melakukan PHK. Mayoritas aktivitas pekerjaan mengalami hambatan, karena terpengaruh oleh kebijakan pemerintah yang membatasi berbagai bentuk kegiatan masyarakat. Responden mengatakan bahwa beban kerja menjadi berkurang, sehingga terkadang menimbulkan kebosanan dalam bekerja. Pekerjaan kedua responden berhubungan dengan kerjasama bersama pihak eksternal. Responden A merupakan staf divisi Legal atau Pengurusan Kontrak yang bertugas mengatur segala urusan perjanjian dan kontrak, sedangkan responden B merupakan staf divisi Pengadaan Barang. Dalam situasi sekarang mereka terhambat untuk menyelesaikan pekerjaan dengan optimal, karena terkendala untuk mengadakan pertemuan dengan pihak eksternal. Situasi tersebut berdampak pada perubahan beberapa tugas sebagai upaya adaptasi mereka, seperti mengerjakan tugas lain di luar tugas utama yaitu arsip dokumentasi dan pengawasan.

Locus of control karyawan turut berpengaruh pada tingkat job insecurity karyawan, dibandingkan dengan karyawan dengan lokus kontrol eksternal, karyawan yang memiliki lokus kontrol internal umumnya melihat peristiwa lingkungan memiliki dampak yang lebih kecil dan

\section{4 | Psychophedia Jurnal Psikologi Universitas Buana Perjuangan Karawang}


percaya bahwa mereka memiliki kekuatan untuk melawan ancaman yang ditimbulkan oleh lingkungan mereka (Mitchell \& Moudgill, 1976; Rotter, 1966). Responden A mengatakan bahwa ia sempat mengkhawatirkan masa depan karirnya di perusahaan, karena tidak menutup kemungkinan perusahaan akan kembali melakukan PHK apabila situasi perusahaan tidak mengalami perbaikan. Jika perusahaan mengambil langkah tersebut, responden A meragukan dirinya dapat memperoleh pekerjaan dalam waktu singkat, mengingat umur responden A yang tidak lagi tergolong muda. Berbeda dengan responden $\mathrm{B}$, dimana ia tidak khawatir apabila sampai mengalami PHK. Ia akan mencari pekerjaan baru ataupun membuka bisnis secara mandiri, karena menurutnya pasti ada perusahaan yang tidak mempermasalahkan umur dan lebih mengutamakan kualitas kemampuan calon karyawannya.

$J o b$ insecurity dapat menimbulkan rasa takut, kehilangan kemampuan, dan kecemasan. Pada akhirnya, jika hal ini dibiarkan berlangsung lama karyawan dapat menjadi stres akibat adanya rasa tidak aman dan ketidakpastian akan kelangsungan pekerjaan Ashford et al., (1989). Tidak dapat dipastikan kapan Indonesia sepenuhnya terbebas dari pandemi. Selama Indonesia belum dinyatakan bebas Covid-19, selama itu juga aktivitas masyarakat belum dapat berjalan dengan normal. Hal ini tentunya berdampak pada penurunan jumlah penumpang maskapai penerbangan. Meskipun penerbangan telah dibuka kembali, tampak bahwa jumlah penumpang belum sebanyak sebelumnya. Situasi ini menjadi penentu akan sampai kapan kebijakan pemotongan gaji diterapkan. Responden ingin agar secepatnya kebijakan pemotongan gaji diberhentikan. Mereka mengalami kesulitan finansial dan terpaksa mengurangi berbagai macam pengeluaran. Kedua responden mengalami stres karena tidak dapat dipastikan akan sampai kapan situasi ini berlangsung. Menurut responden A, jika perusahaan dapat memastikan akan sampai kapan pemotongan gaji diberlakukan, hal tersebut cukup membantu menurunkan tingkat kekhawatirannya. Selain itu mereka pun merasa khawatir apabila perusahaan sampai melakukan PHK.

$J o b$ insecurity dapat berhubungan dengan respon penarikan diri sebagai usaha untuk menghindari stres. Semakin besar job insecurity dapat meningkatkan perilaku mencari peluang kerja yang lebih aman (Greenhaigh \& Rosenblatt, 1984). Kedua responden memahami bahwa perusahaan bergerak di bidang penyediaan jasa penerbangan, sehingga operasional perusahaan sangat bergantung pada tingkat permintaan konsumen. Dengan adanya penutupan rute penerbangan ketika masa awal pandemi masuk ke Indonesia, perusahaan mengalami kerugian dalam skala besar. Perusahaan kehilangan sumber pemasukan utama dan berpengaruh pada operasional keseluruhan. Responden membandingkan perusahaan mereka dengan organisasi lain seperti Badan Usaha Milik Negara (BUMN) dan instansi pemerintah. Menurut informasi yang mereka ketahui instansi pemerintah cenderung stabil di tengah situasi pandemi. Pegawai BUMN ataupun Aparatur Sipil Negara (ASN) tidak mengalami pemotongan gaji sehingga dari sisi finansial ASN tidak terkena dampak begitu besar. Hal ini membuat mereka mempertimbangkan kembali perjalanan karir mereka di perusahaan " $X$ ". Menurut kedua responden, situasi seperti ini mungkin terjadi kembali di kemudian hari. Mereka terdorong ingin mencari pekerjaan di instansi pemerintahan yang memiliki tingkat keamanan lebih tinggi dari sisi keamanan karir dan keamanan finansial.

Karyawan dengan job insecurity tinggi akan kurang puas dengan pekerjaan mereka. Apabila karyawan mempersepsikan pekerjaan secara negatif, maka dapat menurunkan tingkat kepuasan kerja Ashford 
et al., (1989). Akibat terbatasnya kesempatan karyawan untuk mengerjakan tugas utama, akhirnya membuat mereka melakukan tugas lain agar tetap dapat produktif seperti melakukan arsip dokumen. Pekerjaan tersebut dirasa sangat monoton dan membosankan. Kedua responden lebih menyukai situasi bekerja sebelum pandemi, dimana mereka dapat dengan optimal menyelesaikan semua tugas. Meskipun di sisi lain, responden A juga merasa senang karena aktivitas saat ini tidak terlalu menguras pikiran dan energi secara intens.

\section{Diskusi}

Hasil penelitian telah menjawab tujuan penelitian yaitu ingin mengetahui gambaran job insecurity pada karyawan maskapai penerbangan " $X$ " di masa pandemi Covid-19. Situasi pandemi yang sudah berlangsung selama satu tahun lebih, menjadi faktor terjadinya perubahan organisasi di maskapai penerbangan " $X$ ". Keberlangsungan maskapai penerbangan " $X$ " akan bergantung pada kebijakan pemerintah dalam rangka menekan penyebaran virus Covid-19. Selama itu pula, proses bisnis maskapai penerbangan " $\mathrm{X}$ " belum dapat pulih seutuhnya. Situasi ini akan menjadi penentu akan sampai kapan maskapai penerbangan " $\mathrm{X}$ " memberlakukan kebijakan dalam rangka mempertahankan efisiensi proses bisnis perusahaan seperti perubahan jadwal kerja, pemotongan gaji, melakukan penyesuaian terhadap tugas dan fungsi karyawan, hingga melakukan PHK.

Ancaman pada aspek pekerjaan karyawan dapat berimbas pada kondisi mental mereka dan berpotensi memunculkan kondisi job insecurity yang ditandai dengan dua dimensi yaitu severity of threat dan powerlessness to counteract the threat. Meskipun demikian, ancaman pada aspek pekerjaan tidak sepenuhnya menjadi faktor anteseden untuk memunculkan job insecurity. Dengan kata lain, meskipun pegawai menerima ancaman yang sama tidak secara otomatis seluruh pegawai akan mengalami job insecurity, karena dapat dipengaruhi oleh locus of control yang dimiliki pegawai. Dibandingkan dengan karyawan dengan locus of control eksternal, karyawan yang memiliki locus of control internal umumnya melihat peristiwa lingkungan memiliki dampak yang lebih kecil dan percaya bahwa mereka memiliki kekuatan untuk melawan ancaman yang ditimbulkan oleh lingkungan mereka. Hal tersebut mempengaruhi tingkat job insecurity karyawan.

Terkait dengan ancaman pada aspek pekerjaan, kedua responden menunjukkan reaksi yang hampir serupa, mereka menerima kebijakan yang ada dan tetap bertahan di perusahaan. Di sisi lain mereka merasa bersyukur karena sampai saat ini perusahaan tidak melakukan PHK terhadap mereka. Tetapi tidak menutup kemungkinan jika di kemudian hari perusahaan kembali melakukan PHK. Menanggapi hal tersebut kedua responden menunjukkan reaksi yang berbeda. Responden A tampaknya memiliki tingkat kekhawatiran yang lebih tinggi, karena meragukan dirinya akan dengan mudah memperoleh pekerjaan pengganti. Sedangkan responden B yakin terhadap kemampuannya untuk kembali mendapatkan pekerjaan.

Kondisi job insecurity pada karyawan memunculkan faktor konsekuen yaitu stres, keinginan untuk turnover, dan kepuasan kerja menurun. Tidak dapat dipastikan akan sampai kapan situasi pandemi ini berlangsung. Selama pandemi masih ada di Indonesia, selama itu pula pemerintah aktif menerapkan kebijakan-kebijakan yang membatasi mobilitas masyarakat dan akan berimbas pada proses bisnis maskapai penerbangan " $X$ ". Responden ingin agar secepatnya kebijakan pemotongan gaji diberhentikan. Mereka mengalami kesulitan finansial dan stres karena tidak dapat dipastikan akan sampai kapan situasi ini berlangsung. Selain itu mereka merasa khawatir atas keamanan karir mereka di perusahaan. Karyawan mengetahui betul bahwa maskapai penerbangan " $\mathrm{X}$ " bergerak 
di bidang pelayanan jasa penerbangan, dimana sumber utama keuangan berasal dari permintaan konsumen. Menurut kedua responden, situasi krisis yang menyerupai mungkin akan kembali terjadi di kemudian hari. Maka dari itu, responden mempertimbangkan bagaimana perjalanan karir mereka di maskapai penerbangan " $\mathrm{X}$ ". Menanggapi hal tersebut, responden ingin mencari pekerjaan baru di instansi pemerintahan karena profesi ASN dianggap memiliki tingkat keamanan karir dan keamanan finansial yang lebih tinggi.

\section{Kesimpulan}

Penelitian ini dapat menggambarkan faktor anteseden yang memunculkan kondisi job insecurity, serta faktor konsekuen sebagai efek dari adanya kondisi job insecurity pada karyawan. Terkait hal ini, karyawan mengalami job insecurity karena adanya kebijakan organisasi selama masa pandemi yang dinilai merugikan karyawan. Kebijakan tersebut menjadi sebuah ancaman bagi karyawan dan menimbulkan kondisi mental yang negatif. Kondisi mental tersebut kemudian menimbulkan stres, keinginan untuk turnover, dan kepuasan kerja menurun.

\section{Kepustakaan}

Artanti, A. A. (2020). 3 Sektor Ini Paling Terdampak Covid-19. In Medcom.Id. https://www.medcom.id/ekonomi/bisnis/ yKXDzE6K-3-sektor-ini-palingterdampak-covid-19

Ashford, S. J., Lee, C., \& Bobko, P. (1989). Content, Cause, And Consequences Of Job Insecurity: A Theory-Based Measure And Substantive Test. Academy Of Management Journal. https://doi.Org/10.2307/256569

Braun, V., \& Clarke, V. (2006). Using thematic analysis in psychology. Qualitative Research in Psychology. https://doi.org/10.1191/1478088706qp06 3oa
Gitiyarko, V. (2020). Kebijakan Pemerintah Menangani Covid-19 Sepanjang Semester II 2020. In Kompas Pedia. https://kompaspedia.kompas.id/baca/pap aran-topik/kebijakan-pemerintah menangani-covid-19-sepanjangsemester-ii-2020

Greenhalgh, L., \& Rosenblatt, Z. (1984). Job Insecurity: Toward Conceptual Clarity. Academy of Management Review. https://doi.org/10.5465/amr.1984.427967 3

Hadiwinata. (2020). Sebesar Ini Penurunan Jumlah Penumpang Pesawat Udara Sepanjang 2020. https://insight.kontan.co.id/news/sebesarini-penurunan-jumlah-penumpangpesawat-udara-sepanjang-2020

Mitchell, V. F., \& Moudgill, P. (1976). Measurement of maslow's need hierarchy. Organizational Behavior and Human Performance. https://doi.org/10.1016/00305073(76)90020-9

Rotter, J. B. (1966). Generalized expectancies for internal versus external control of reinforcement. In Psychological monographs. https://doi.org/10.1037/h0092976

Sayekti. (2020). Dampak ekonomi pandemi Covid-19. In Sayekti. https://analisis.kontan.co.id/news/dampa k-ekonomi-pandemi-covid-19

Simatupang, M. (2017). Gambaran keharmonisan commuter family pada anggota Brigade Kepolisian Daerah Sumatera Utara. Analitika: Jurnal Magister Psikologi UMA, 9(1), 27-35.

Sugiyono. (2012). Metode Penelitian Kuantitatif, Kualitatif dan R \& D.Bandung:Alfabeta. Metode Penelitian Kuantitatif, Kualitatif Dan $R \quad \&$ D.Bandung:Alfabeta. https://doi.org/10.1017/CBO9781107415 324.004 